\title{
Meta-Analysis: The Effect of Diabetes Mellitus Comorbidity on the Risk of Death in Covid-19 Patients
}

\author{
Utin Ilma Agni Kun'ain'), Setyo Sri Rahardjo²), Didik Gunawan Tamtomo²) \\ 1)Masters Program in Public Health, Universitas Sebelas Maret \\ ${ }^{2)}$ Faculty of Medicine, Universitas Sebelas Maret
}

\section{ABSTRACT}

Background: Corona Virus Deases 2019 (COVID-19) is an infectious disease caused by the corona virus. COVID-19 is currently a challenge for diabetes patients. Diabetes mellitus predisposes to a very severe disease course and increases the risk of death from COVID-19. This study aims to estimate the average magnitude of the effect of diabetes mellitus comorbidity on the risk of death of COVID-19 patients.

Subjects and Method: This was a systematic review and meta-analysis. This research was conducted using secondary data that will be conducted by searching and selecting data from the results of clinical trials conducted around the world. Search for articles through systematic and comprehensive databases from Pubmed, Google Scholar, Springer Link. The analysis in this study was carried out using the Review Manager 5.3 software. The results of the analysis are the effect size, heterogeneity and then the study model. Variations between studies are used to determine the analysis model which is divided into two models, namely the fixed effect model (FEM) and the random effect model (REM).

Results: Based on the results of the analysis, there was high heterogeneity between experiments $\left(I^{2}=85 \% ; p=0.04\right)$, so that the Random Effects Model (REM) was used. COVID-19 patients with comorbid diabetes mellitus were 2.17 times more likely to die than patients without comorbid diabetes mellitus (aOR 2.17; 95\% CI 1.04 to 4.54 ).

Conclusion: Diabetes mellitus co-morbidity increases 2.17 times the risk of death in COVID19 patients compared to patients without diabetes mellitus comorbidity.

Keywords: COVID-19, Comorbidity, Diabetes Mellitus, Death

\section{Correspondence:}

Utin Ilma Agni Kun'ain. Masters Program in Public Health, Universitas Sebelas Maret. Jl. Ir. Sutami 36 A, Surakarta 57126, Central Java. Email: utinilmaagni8p@gmail.com. Mobile: +628111044542 .

Cite this as:

Kun'ain UIA, Rahardjo SS, Tamtomo DG (Year). Meta-Analysis: The Effect of Diabetes Mellitus Comorbidity on the Risk of Death in Covid-19 Patients. Indones J Med. 05(04): 368-377. https://doi.org/10.26911/theijmed.2020.05.04.12.

(c) (i) (9) (2) Indonesian Journal of Medicine is licensed under a Creative Commons

\begin{abstract}
BACKGROUND
Corona Virus Deases 2019 (COVID-19) is an infectious disease caused by the corona virus (WHO, 2019). On December 31, 2019 the Wuhan Municipal Health Commission reported a case of pneumonia in Wuhan, Hubei Province. On January 5, 2020 the World Health Organization (WHO) announced news of the COVID-19 outbreak (WHO, 2020). The COVID-19 disease
\end{abstract}

causes a global health crisis, disrupting social, economic and political aspects. Doctors, health workers, scientists, organizational groups and governments are fighting against COVID-19 (Jeong et al., 2020).

Diabetes Mellitus (DM) is one of the main diseases that threatens the health of the global population (Budiarti et al., 2017). Diabetes Mellitus is a non-communicable disease with a high prevalence of complica- 
tions and mortality at productive age (Pranoto et al., 2017). Morbidity and mortality due to diabetes are associated with the development of various microvascular complications (retinopathy, nephropathy, and neuropathy) and macrovascular complications (coronary heart disease, stroke and peripheral vascular disease) (Handoko et al., 2018). Diabetics are prone to infection due to hyperglycemia (Jeong et al., 2020).

There is clinical evidence that diabetic patients are at a higher risk of contracting Coronavirus 2019 (Marhl et al., 2020). COVID-19 is currently a challenge for diabetes patients. Diabetes mellitus predisposes to a very severe disease course and increases the risk of death from COVID-19. In addition, diabetic patients who have comorbidities will worsen clinical outcomes (Peric et al., 2020). In Yan's study, it was revealed that the mortality rate in patients with COVID-19 with diabetes was quite large. Diabetes can lead to an increased risk of death (Yan et al., 2020).

COVID-19 patients with diabetes are at risk of severity caused by Severe Acute Respiratory Syndrome Coronavirus 2 (SARS-CoV-2). Angiotensin-Converting Enzyme 2 (ACE2) is expressed in several tissues, including the salivary glands and pancreas. In the pancreas, SARS-CoV was previously found to reduce insulin release in which diabetes mellitus patients are heavily dependent on insulin. SARS-CoV-2 infection has been shown to cause ketosis or ketoacidosis and to cause diabetic ketoacidosis in those with diabetes. SARS-CoV2 can also infect and cause damage to $\alpha$ cells and $\beta$ cells of the pancreas (Pedrosa et al., 2020).

The overall symptoms of COVID-19 in all patients were sore throat, fever, dry cough, fatigue and diarrhea. In diabetes mellitus patients, there are no definite data about different symptoms. The Inter- national Diabetes Federation (IDF) statement reports that symptoms in diabetics are no different from other sufferers of COVID19. Symptoms in diabetes mellitus patients are more developed (Abdi et al., 2020).

The results of Aggarwal's study show that the risk of death likelihood in patients with a history of diabetes mellitus is increased 2 times compared to those without diabetes mellitus (Aggarwal, Lippi, Lavie, Henry and Sanchis-Gomar, 2020). This study aims to estimate the average magnitude of the effect of diabetes mellitus comobidity on the risk of death of COVID-19 patients.

\section{SUBJECTS AND METHOD a. Study Design}

This was a systematic review and meta-analysis. This research was conducted using secondary data that will be conducted by searching and selecting data from the results of clinical trials conducted around the world. Search for articles through systematic and comprehensive databases from Pubmed, Google Scholar, Springer Link. The keywords used to find the article were "COVID-19 and comorbidity", "COVID-19 and mortality and diabetes mellitus", "COVID-19 and diabetes mellitus and adjusted", "COVID-19 and diabetes mellitus and mortality and adjusted".

\section{b. Inclusion Criteria}

The inclusion criteria for articles used were full paper articles with observational studies (retrospective or prospective), primary studies conducted in the hospital. The research subjects were adult patients with COVID-19. The articles are those published in English.

\section{c. Exclusion Criteria}

The exclusion criteria for the articles used were cross-sectional, case-control, quasiexperimental, study subjects were children and pregnant women. 
Kun'ain et al./ Diabetes Mellitus Comorbidity on the Risk of Death in Covid-19 Patients

\section{d. Operational Definition ofVariable}

Death in COVID-19 patients is when the function of the heart, circulation and respiratory system is proven to have stopped permanently. The results of the measurement of this study were either died or did not die.

\section{e. Instruments}

The instrument used in the study was a published article regarding the effect of diabetes mellitus comorbidity on the risk of death in COVID-19 patients. The articles are published from 2019 to 2020. Article searches are conducted through a systematic and comprehensive database from Pubmed, Google Scholar, Springer Link.

\section{f. Data Analysis}

The analysis in this study was carried out using the Review Manager 5.3 software. The results of the analysis are the effect size, heterogeneity and then the study model. Variations between studies are used to determine the analysis model which is divided into two models, namely the fixed effect model (FEM) and the random effect model (REM).

\section{RESULTS}

The process of searching for articles in the flow diagram below is through the Pubmed, Google Scholar, and Springer Link databases published from 2019 to 2020.

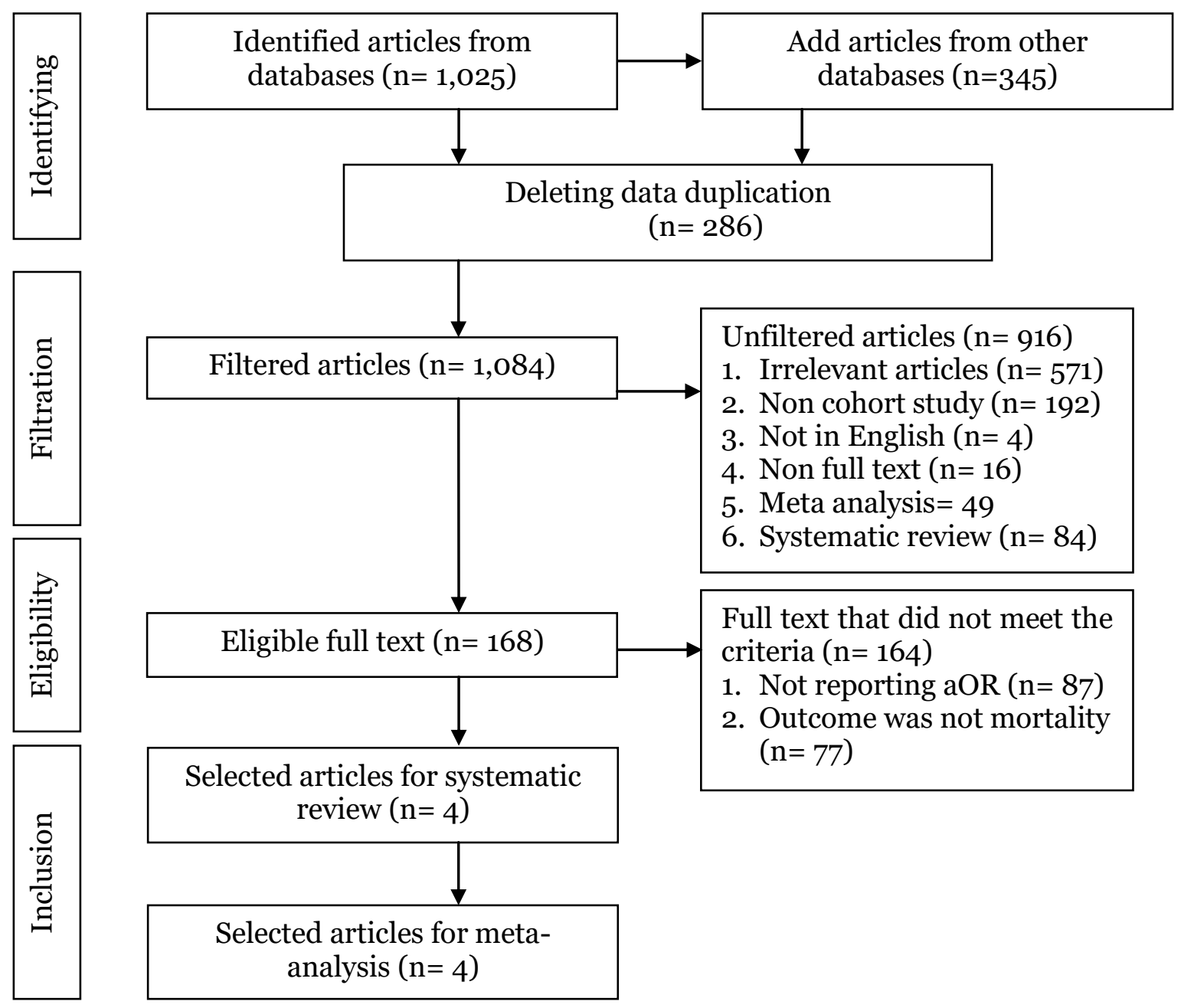

Figure 1. Research Steps with PRISMA Flow Diagram 
The results of the search for articles from several databases obtained 1370 identified articles, then double data deletion was carried out as many as 286 articles so that 1084 articles were filtered. Based on the filtered articles, there were 916 articles that had to be issued and 164 articles were deemed eligible. Several full text articles after the review did not qualify because the study outcome was not death in COVID-19 patients and did not mention aOR or multilevel analysis. Articles that have met the qualitative requirements were reviewed again and obtained 4 articles that met the requirements and also met the quantitative requirements so that a meta analysis could be carried out.

The identified studies were then assessed for each study based on the eligibility criteria. The quality and design of the research analyzed in the meta-analysis is very important because it affects the results. Assessment of the quality of the study is carried out quantitatively and qualitatively. Assessment of quality in this study was done using the Quality Assessment Tools for Observational Cohort and Cross-Sectional Studies published by NIH (National Institutes of Health).

This assessment criterion uses a combined score of fourteen criteria, with each criterion being given a score of 1 if the answer is yes and given a score of $o$ if the answer is no. The study is categorized as good quality if the score is $\geq 8$, sufficient quality scores $6-7$, and poor quality $<6$. The studies in this study are of good quality.

Based on table 2, there are 4 articles identified from the review results that qualify as a meta-analysis source of the effect of diabetes mellitus comorbidity on the risk of death of COVID-19 patients.

\begin{tabular}{|c|c|c|c|c|c|c|c|c|}
\hline Study or Subgroup & log[Odds Ratio] & SE & Weight & $\begin{array}{c}\text { Odds Ratio } \\
\text { IV, Random, } 95 \% \mathrm{Cl}\end{array}$ & & $\begin{array}{r}\text { Odds } \\
\text { IV, Rando }\end{array}$ & $\begin{array}{l}\text { Ratio } \\
\mathrm{m}, 95 \% \mathrm{Cl}\end{array}$ & \\
\hline Chen 2020 & 0.0677 & 0.0661 & $35.2 \%$ & $1.07[0.94,1.22]$ & & & & \\
\hline Moon 2020 & 1.6958 & 0.6436 & $17.4 \%$ & $5.45[1.54,19.24]$ & & & & \\
\hline Ren 2020 & 1.0296 & 0.7073 & $15.8 \%$ & $2.80[0.70,11.20]$ & & & & \\
\hline Yu 2020 & 0.9243 & 0.2254 & $31.6 \%$ & $2.52[1.62,3.92]$ & & & $\rightarrow$ & \\
\hline Total $(95 \% \mathrm{Cl})$ & & & $100.0 \%$ & $2.17[1.04,4.54]$ & & & & \\
\hline \multicolumn{5}{|c|}{$\begin{array}{l}\text { Heterogeneity: } \operatorname{Tau}^{2}=0.40 ; \mathrm{Chi}^{2}=20.65, \mathrm{df}=3(\mathrm{P}=0.0001) ; \mathrm{I}^{2}=85 \% \\
\text { Test for overall effect: } Z=2.06(P=0.04)\end{array}$} & 0.001 & $\begin{array}{l}0.1 \\
\text { Tidak DM }\end{array}$ & DM & 1000 \\
\hline
\end{tabular}

\section{Figure 2. Forest Plot of the Effect of Diabetes Mellitus Comorbidity} on the Death Risk of COVID-19 Patients

Based on the results of the analysis in Figure 2, it can be seen that as many as 4 articles report that the comorbidity of diabetes mellitus increases the risk of death in COVID-19 patients. Based on the results of the analysis, there was high heterogeneity between experiments ( $\mathrm{I}_{2}=85 \%$; $\mathrm{p}=0.04$ ) so that the Random Effects Model (REM) was used. COVID-19 patients with comorbid diabetes mellitus were 2.17 times more likely to die than patients without comorbid diabetes mellitus $(\mathrm{aOR}=2.17 ; 95 \% \mathrm{CI}=1.04$ to $4 \cdot 54)$. 
Table 1. Critical Appraisal Checklist Effect of Diabetes Mellitus Comorbidity on Death Risk for COVID-19 Patients

\begin{tabular}{|c|c|c|c|c|}
\hline \multirow{2}{*}{ Checklist of Question } & \multicolumn{4}{|c|}{$\begin{array}{c}\text { Publication } \\
\text { (Author and Year) }\end{array}$} \\
\hline & $\begin{array}{l}\text { (Moon et } \\
\text { al., 2020) }\end{array}$ & $\begin{array}{l}\text { (Ren et } \\
\text { al., 2020) }\end{array}$ & $\begin{array}{l}\text { (Chen et } \\
\text { al., 2020) }\end{array}$ & $\begin{array}{l}\text { (Yu et al., } \\
\text { 2020) }\end{array}$ \\
\hline Is the question or research objective in the article clearly stated? & 1 & 1 & 1 & 1 \\
\hline Is the study population clearly defined? & 1 & 1 & 1 & 1 \\
\hline Is the participation rate of those who meet the requirements at least $50 \% ?$ & 1 & 1 & 1 & 1 \\
\hline $\begin{array}{l}\text { Were all subjects selected from the same or similar population (including the same } \\
\text { time period)? Were the inclusion and exclusion criteria for being in the study } \\
\text { predetermined and applied uniformly to all participants? }\end{array}$ & 1 & 1 & 1 & 1 \\
\hline $\begin{array}{l}\text { Are sample size justifications, strength descriptions, or estimates of variance and } \\
\text { effects provided? }\end{array}$ & 1 & 1 & 1 & 1 \\
\hline $\begin{array}{l}\text { For the in-article analysis, is the exposure of interest measured before the outcome is } \\
\text { measured? }\end{array}$ & o & o & o & o \\
\hline $\begin{array}{l}\text { Is the timeframe sufficient that one can expect to see a relationship between exposure } \\
\text { and outcome if any? }\end{array}$ & 1 & 1 & 1 & 1 \\
\hline $\begin{array}{l}\text { For exposures that can vary in number or level, does the study examine the different } \\
\text { levels of exposure in relation to the outcome (for example, the exposure category, or } \\
\text { the exposure measured as a continuous variable)? }\end{array}$ & 1 & 1 & 1 & 1 \\
\hline $\begin{array}{l}\text { Are the measures of exposure (independent variable) clearly defined, valid, reliable } \\
\text { and consistently applied across all study participants? }\end{array}$ & 1 & 1 & 1 & 1 \\
\hline Was exposure assessed more than once over time? & $\mathrm{O}$ & $\mathrm{O}$ & $\mathrm{O}$ & $\mathrm{O}$ \\
\hline $\begin{array}{l}\text { Are outcome measures (dependent variable) clearly defined, valid, reliable, and } \\
\text { consistently applied across all study participants? }\end{array}$ & 1 & 1 & 1 & 1 \\
\hline Did the outcome assessors not know the participant's exposure status? & $\mathrm{o}$ & $\mathrm{O}$ & $\mathrm{O}$ & 0 \\
\hline Was loss to follow-up after baseline $20 \%$ or less? & $\mathrm{O}$ & $\mathrm{O}$ & $\mathrm{O}$ & $\mathrm{O}$ \\
\hline $\begin{array}{l}\text { Were the main potential confounding variables measured and statistically adjusted for } \\
\text { their impact on the relationship between exposure and outcome? }\end{array}$ & 1 & 1 & 1 & 1 \\
\hline Total & 10 & 10 & 10 & 10 \\
\hline
\end{tabular}

Note:

1: Yes

o: No 
Table 2. Summary Source Effect of Diabetes Mellitus Comorbidity on Death Risk for COVID-19 Patients

\begin{tabular}{|c|c|c|c|c|c|c|c|c|}
\hline \multirow[b]{2}{*}{$\begin{array}{c}\text { Author } \\
\text { (Year) }\end{array}$} & \multirow[b]{2}{*}{ Country } & \multirow[b]{2}{*}{ Study } & \multicolumn{2}{|c|}{ Total number } & \multirow[b]{2}{*}{ Population (P) } & \multirow[b]{2}{*}{ Intervention (I) } & \multirow[b]{2}{*}{ Comparison (C) } & \multirow[b]{2}{*}{ Outcome (O) } \\
\hline & & & $\begin{array}{l}\text { Patient of } \\
\text { COVID-19 }\end{array}$ & $\begin{array}{l}\text { Patient of } \\
\text { DM }\end{array}$ & & & & \\
\hline $\begin{array}{l}\text { (Moon et } \\
\text { al., 2020) }\end{array}$ & $\begin{array}{l}\text { South } \\
\text { Korea }\end{array}$ & Kohort & 352 & 57 & $\begin{array}{l}\text { Patient confirmed } \\
\text { COVID-19 }\end{array}$ & $\begin{array}{l}\text { Patient age }<70 \text { years, } \\
\text { history of diabetes, } \\
\text { temperature }<37.5\end{array}$ & $\begin{array}{l}\text { Patient age }>70 \text { years, } \\
\text { no history of diabetes, } \\
\text { temperature }>37.5\end{array}$ & $\begin{array}{l}\text { Death of a Covid-19 } \\
\text { patient hospitalized }\end{array}$ \\
\hline $\begin{array}{l}\text { (Ren et al., } \\
\text { 2020) }\end{array}$ & Cina & Kohort & 151 & 39 & $\begin{array}{l}\text { Patient confirmed } \\
\text { COVID-19 }\end{array}$ & $\begin{array}{l}\text { Patients who have a } \\
\text { history of diabetes } \\
\text { mellitus }\end{array}$ & $\begin{array}{l}\text { Patients with no history } \\
\text { of diabetes mellitus }\end{array}$ & $\begin{array}{l}\text { The severity and } \\
\text { mortality of patients } \\
\text { diagnosed with } \\
\text { COVID-19 }\end{array}$ \\
\hline $\begin{array}{l}\text { (Chen et } \\
\text { al., 2020) }\end{array}$ & Cina & Kohort & 904 & 136 & $\begin{array}{l}\text { Patient confirmed } \\
\text { COVID-19 }\end{array}$ & $\begin{array}{l}\text { The group with } \\
\text { diabetes mellitus }\end{array}$ & $\begin{array}{l}\text { The group without } \\
\text { diabetes mellitus }\end{array}$ & $\begin{array}{l}\text { Mortality and poor } \\
\text { prognosis in COVID- } \\
19 \text { patients }\end{array}$ \\
\hline $\begin{array}{l}\text { (Yu et al., } \\
2020)\end{array}$ & Cina & Kohort & 1464 & 211 & $\begin{array}{l}\text { Patient confirmed } \\
\text { COVID-19 }\end{array}$ & $\begin{array}{l}\text { Age }<65 \text { years, male, } \\
\text { have a history of } \\
\text { hypertension, have a } \\
\text { history of diabetes } \\
\text { mellitus, lymphopenia } \\
(<1.1 \times 109 \text { / liter }(\mathrm{L})\end{array}$ & $\begin{array}{l}\text { Age }>65 \text { years, no } \\
\text { history of hypertension, } \\
\text { no history of diabetes } \\
\text { mellitus, lymphopenia } \\
(\geq 1.1 \times 109 / \mathrm{L})\end{array}$ & $\begin{array}{l}\text { Risk factors for death } \\
\text { in COVID-19 patients }\end{array}$ \\
\hline
\end{tabular}




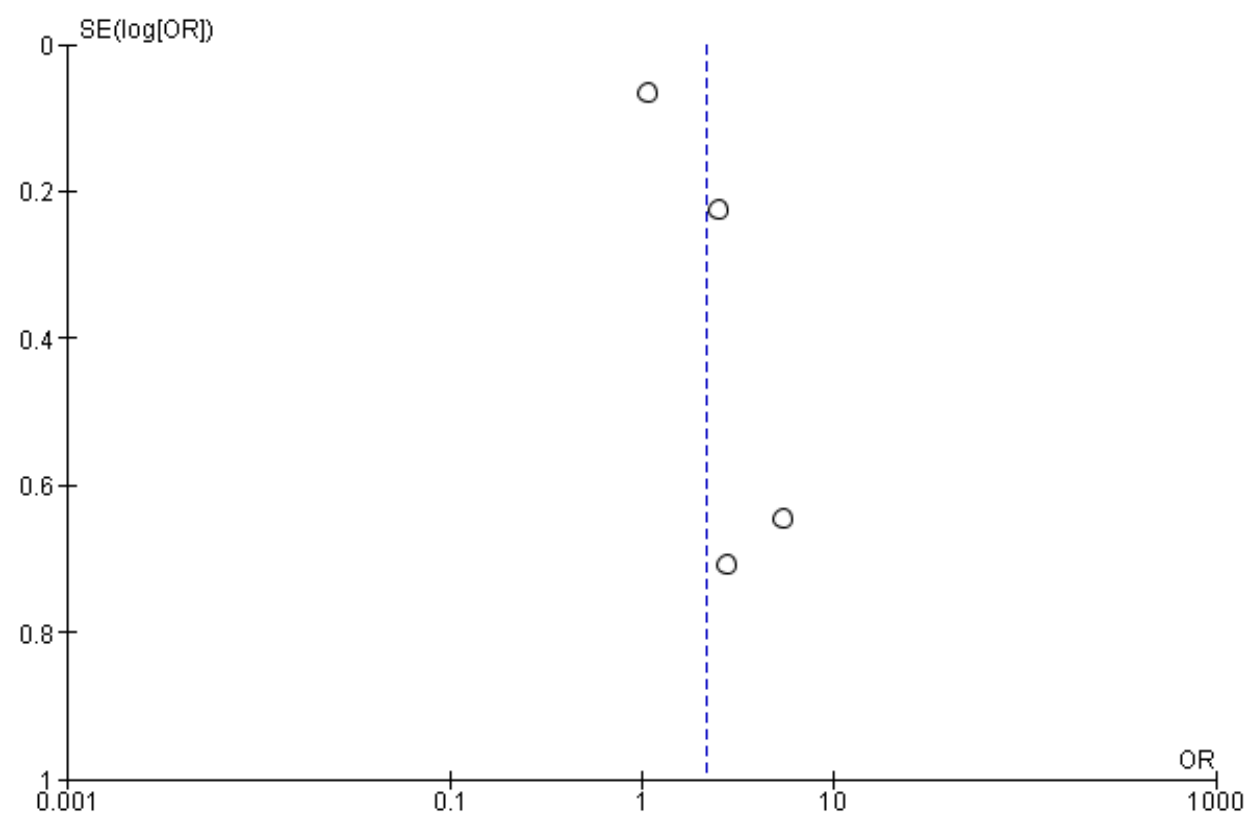

\section{Figure 3. Funnel Plot of the Effect of Diabetes Mellitus Comorbidity on the Death Risk of COVID-19 patients}

Based on Figure 3 funnel plot the effect of diabetes mellitus comorbidity on the risk of death of Covid-19 patients, the plots on the right and left are not symmetrical with each other and do not form an inverted funnel. The left plot has a standard error $>0$ and the right plot has a standard error between $>0.2$ to $>0.6$, this indicates that in this study there is a publication bias in the study.

\section{DISCUSSION}

Severe Acute Respiratory Syndrome Coronavirus (SARS-CoV)2 a new virus which indicates that the pathogen is Coronavirus $(\mathrm{CoV})$ and this virus has spread throughout the world so that the World Health Organization (WHO) declared a pandemic (Pascarella et al., 2020) . This virus was first named 2019-nCoV and subsequently the disease was renamed by WHO to COVID19. COVID-19 is the seventh member of the Coronaviridae known to infect humans (Sun et al., 2020). The clinical symptoms of COVID-19 have similarities with SARS-
CoV, namely fever, cough, dipsnea, chest pain, fatigue, myalgia, diarrhea, nausea and vomiting (Harapan et al., 2020). The confirmed cases of COVID-19 were carrying out laboratory examinations of Reverse-Transcriptase Polymerase-Chain-Reaction (RTPCR) and chest Computed Tomography (CT) Scan (Ge et al., 2020).

Diabetes is a risk factor that influences the development and prognosis of COVID-19 due to ongoing inflammation and impaired immune response (Zhou et al., 2020). Complementary diseases and symptoms that accompany COVID-19 infection include diabetes mellitus, hypertension, cardiovascular disease, and chronic obstructive pulmonary disease. Diabetes mellitus is considered to be one of the critical comorbidities, which can affect the survival of infected patients. The severity of COVID-19 disease increases in patients with elevated glucose levels through a strengthened pro-inflammatory cytokine response, poor innate immunity and down- 
Kun'ain et al./ Diabetes Mellitus Comorbidity on the Risk of Death in Covid-19 Patients

regulated angiotensin 2-converting enzymes (Das et al., 2020).

COVID-19 infects the lung tissue through the receptor Angiotensin Converting Enzym 2 (ACE2). Individuals with diabetes have elevated ACE2. Medications such as ACE inhibitors, GLP-1 agonists, and statins can further increase ACE2 levels. Increased glucose levels allow the replication of SARS-CoV-2. Increased expression of ACE2 receptors in several tissues in diabetes, the severity of COVID-19 may be higher (Erener, 2020). Diabetic patients are more susceptible to infection in general and show a worse prognosis after infection than non-diabetic patients. Patients with diabetes mellitus have a greater incidence of decreased lymphocyte counts and increased neutrophil counts, as well as higher levels of serum Interleukin-6 (IL-6), CRP, and Lactic Dehydrogenase (LDH) accompanied by higher blood glucose levels comparedto the non-diabetic group The association between diabetes and a worse outcome in viral infection was unexpected because hyperglycemia impairs control of viremia and inflammation, exacerbating morbidity and mortality in various patients ( $\mathrm{Zhu}$ et al., 2020).

This study is supported by ( $\mathrm{Li}$ et al., 2020) that the mortality rate of COVID-19 patients with diabetes is significantly higher than those without diabetes. Higher levels of D-dimers and a lymphocyte count less than $0.6 \times 109 / \mathrm{L}$ at admission were risk factors associated with death in hospital. Research (Aggarwal et al., 2020) explains that patients with a history of diabetes mellitus have a 2-fold risk of death, so patients with a history of diabetes mellitus must be closely monitored if they are infected with COVID-19. Research (Miller et al., 2020) states that in a meta-analysis of hospitalized patients in China with a diagnosis of COVID-19 the mortality rate is
9.9\% with a higher prevalence of diabetes mellitus with a worse prognosis.

\section{AUTHOR CONTRIBUTION}

Utin Ilma Agni Kun'ain is the main author collected and did data analysis. Setyo Sri Rahardjo examined the conceptual framework and methodology, and interpreted the results. Didik Gunawan Tamtomo reviewed the manuscript

\section{CONFLICT OF INTEREST}

There is no conflict of interest in this study.

\section{FUNDING AND SPONSORSHIP}

This study does not use fees because of secondary data and uses a database that can be accessed and provides open access journals.

\section{ACKNOWLEDGEMENT}

We would like to thank the databases (PubMed, Science Direct, and Springer Link) which have provided information and data on published journals.

\section{REFERENCE}

Abdi A, Jalilian M, Sarbarzeh PA, Vlaisavljevic $Z$ (2020). Diabetes and COVID19: A systematic review on the current evidences. Diabetes Res Clin Pract. 166: 108347. doi: 10.1016/j.diabres.2020.-108347.

Aggarwal G, Lippi G, Lavie CJ, Henry BM, Sanchis-Gomar F (2020). Diabetes mellitus association with coronavirus disease 2019 (COVID-19) severity and mortality: A pooled analysis. Journal of Diabetes. 12(11): 851-855. doi: 10.1111/1753-0407.13091.

Budiarti E, Tamtomo DG, Adriani RB (2017). Path analysis on the biopsychosocial determinants of type 2 diabetes mellitus and depression at Dr. Moewardi Hospital, Surakarta. J 
Kun'ain et al./ Diabetes Mellitus Comorbidity on the Risk of Death in Covid-19 Patients

Epidemiol Public Health. 03(01): 114. doi: 10.26911/jepublichealth.2018.03.01.01.

Chen Y, Yang D, Cheng B, Chen J, Peng A, Yang C, Liu C, et al. (2020). Clinical characteristics and outcomes of patients with diabetes and covid-19 in association with glucose-lowering medication. Diabetes care. 43: 13991407. doi: 10.2337/dci20-0035.

Das S, Anu KR, Birangal S, Nikam AN, Pandey A, Mutalik S, Joseph A (2020). Role of comorbidities like diabetes on severe acute respiratory syndrome coronavirus-2: A review. Life sciences. 258: 118202. doi: 10.1016/j.lfs.2020.118202.

Erener S (2020). Diabetes, infection risk and COVID-19. Molecular Metabolism. 101044. doi: 10.1016/j.molmet.2020.101044.

Ge H, Wang X, Yuan X, Xiao G, Wang C, Deng T, Yuan Q, et al. (2020). The epidemiology and clinical information about COVID-19. European Journal of Clinical Microbiology and Infectious Diseases. 1011-1019. doi: 10.1007/s10096-020-03874-z.

Handoko, Setyo SR, Murti B (2018). Predictors of macro and microvascular complication in type 2 diabetes mellitus patients at Dr. Moewardi Hospital, Surakarta. Indones J Med. 3(1): 1-13. doi: 10.26911/theijmed.2018.03.01.01.

Harapan H, Itoh N, Yufika A, Winardi W, Keam S, Te H, Megawati D, et al. (2020). Coronavirus disease 2019 (COVID-19): A literature review. Journal of Infection and Public Health. 667-673. doi: 10.1016/j.jiph.2020.03.019 .

Jeong IK, Yoon KH, Lee MK (2020). Diabetes and COVID-19: Global and regional perspectives. Diabetes Research and Clinical Practice. 166. doi: 10.1016/j.diabres.2020.-108303.

Li G, Deng Q, Feng J, Li F, Xiong N, He Q (2020). Clinical characteristics of diabetic patients with COVID-19. Journal of Diabetes Research. doi: 10.1155/2020/165-2403.

Marhl M,Grubelnik V,MagdicM,Markovic R (2020). Diabetes and metabolic syndrome as risk factors for COVID-19. Clinical Research and Reviews. 14(4): 671-677. doi: 10.1016/j.-dsx.2020.05.013 .

Miller LE, Bhattacharyya R, Miller AL (2020). Diabetes mellitus increases the risk of hospital mortality in patients with Covid-19: Systematic review with meta-analysis. Medicine. NLM (Medline), 99(40): e22439. doi: 10.1097/MD.0-000000000022439.

Moon S, Lee K, Park J, Yun S, Lee YS, Lee DS (2020). Clinical characteristics and mortality predictors of COVID-19 patients hospitalized at NationallyDesignated Treatment Hospitals. Journal of Korean medical science. NLM (Medline), 35(36), p. e328. doi: 10.3346/jkms.2020.35.e328.

Pascarella G, Strumia A, Piliego C, Bruno F, Del BR, Costa F, Scarlata S, et al. (2020). COVID-19 diagnosis and management: a comprehensive review. Journal of Internal Medicine. 288(2): 192-206. doi: 10.1111/joim.13091.

Pedrosa MS, Neves NF (2020). COVID-19 and diabetes: What should we expect?. Journal of Diabetes Science and Technology. 1133-1134. doi: 10.1177/1932296-820948041.

Peric S, Stulnig TM (2020). Diabetes and COVID-19: Disease-ManagementPeople. Wiener Klinische Wochenschrift. Springer Medizin, 132(13-14): 356-361. doi: 10.1007/soo508-02001672-3. 
Pranoto HP, Tamtomo D, Murti B (2017). The roles of medical doctor and family on patient health behavior in controlling $\mathrm{HbA1C}$ level among patients with type 2 diabetes mellitus at Dr. Moewardi Hospital. Indonesian Journal of Medicine. 02(01): 21-34. doi: 10.26911/the-ijmed.2017.02.01.03.

Ren H, Yang Y, Wang F, Yan Y, Shi X, Dong K, Yu X, Zhang S (2020). Association of the insulin resistance marker TyG index with the severity and mortality of COVID-19. Cardiovascular Diabetology. BioMed Central: 1-8. doi: 10.1186/s12933-020-01035-2.

Sun J, He W, Wang L, Lai A, Ji X, Zhai X, Li G, et al. (2020). COVID-19: Epidemiology, evolution, and cross-disciplinary perspectives. Trends in Molecular Medicine. 483-495. doi: 10.1016/j.molmed.2020.02.008.

Yan Y, Yang Y, Wang F, Ren H, Zhang S, Shi X, Yu X, et al. (2020). Clinical characteristics and outcomes of patients with severe covid-19 with dia- betes. BMJ Open Diabetes Research and Care. BMJ Publishing Group, 8(1): 1343. doi: 10.1136/bmjdrc-2020001343.

Yu C, Lei Q, Li W, Wang X, Liu W, Fan X, Li W (2020). Clinical characteristics, associated factors, and predicting COVID-19 mortality risk: A retrospective study in Wuhan, China. American Journal of Preventive Medicine. 59(2). doi: 10.1016/j.amepre.2020.05.002.

Zhou W, Ye S, Wang W, Li S, Hu Q, Masaki $\mathrm{T}$ (2020). Clinical features of COVID19 patients with diabetes and secondary hyperglycemia. Journal of Diabetes Research. Hindawi Limited, 2020: 1-9. doi: 10.1155/2020/3918723.

Zhu L, She ZG, Cheng X, Qin JJ, Zhang XJ, Cai J, Lei F, et al (2020). Association of blood glucose control and outcomes in patients with COVID-19 and preexisting type 2 diabetes. Cell Metabolism. Cell Press, 31(6): 1068-1077.e3. doi: 10.1016/j.cmet.2020.-04.021. 